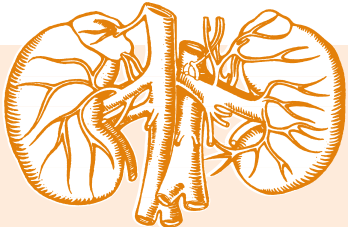 \\ IMÁGENES \\ EN UROLOGÍA
}

(1)

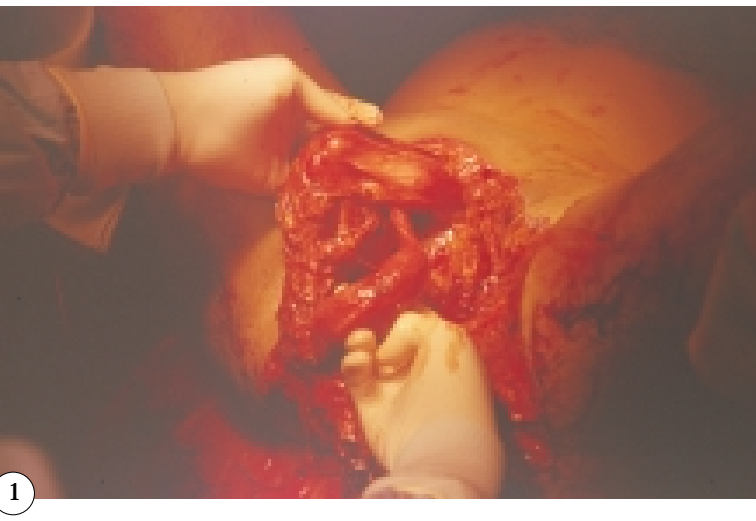

2

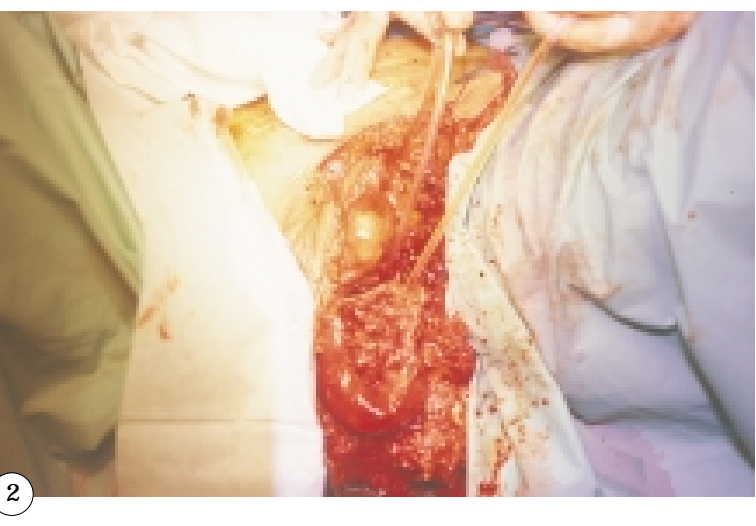

(3)

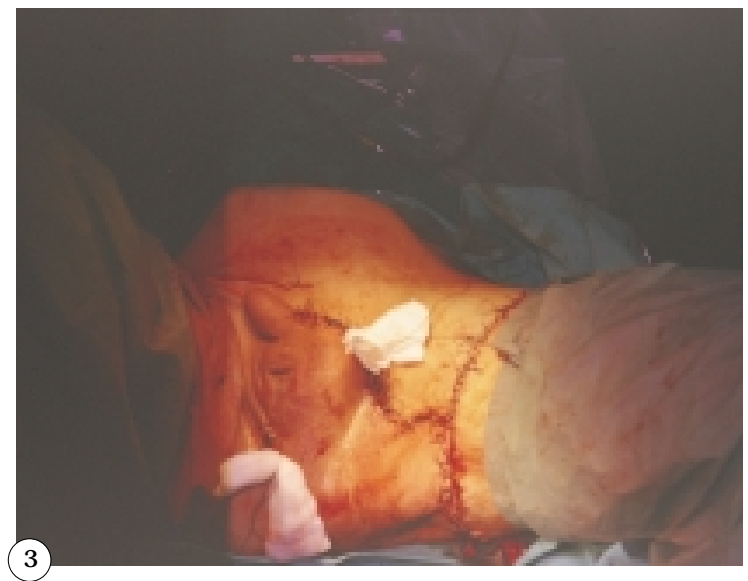

\section{LESIÓN EN DEDO DE GUANTE DEL PENE CON ROTURA COMPLETA DE URETRA POSTERIOR}

Paciente que ingresó en urgencias tras sufrir aplastamiento por un tractor. En el lugar del accidente, y antes de la llegada de la UVI móvil, se procedió a su extracción provocándole un arrancamiento con desgarro de piel y tejidos subcutáneos a nivel hipogástrico y perineal (Fig. 1).

Se realizó exploración quirúrgica bajo anestesia general encontrándose fractura conminuta de sinfisis de pubis y ramas isquio e iliopubianas, desgarro de pared vesical y lesión en "dedo de guante" del pene con rotura completa de uretra posterior a nivel del ápex prostático.

Se llevó a cabo retirada de restos óseos, cierre vesical en dos planos, subinvaginación del pene en su piel y realineamiento de uretra mediante la colocación de sonda uretral y cistostomia suprapúbica, con sutura término-terminal uretral (Fig. 2).

Finalmente se procedió a la sutura de piel y colocación de drenajes (Fig. 3).

En la actualidad y tras un año de evolución, el paciente está continente, habiéndose observado una fistula vésico-cutánea pendiente de reparar.

A. Jalón Monzón, J.J. Rodríguez Martínez, J. García Rodríguez, J.M. Fernández Gómez,

O. Rodríguez Faba, J. Regadera Sejas

Servicio de Urología. Hospital Universitario Central de Asturias. Oviedo (Asturias). 